\title{
APPLICATION OF ARC HYDRO AND HEC-HMS MODEL TECHNIQUES FOR RUNOFF SIMULATION IN THE HEADWATER AREAS OF COVASNA WATERSHED (ROMANIA)
}

\author{
Carina STRAPAZAN ${ }^{1}$, Mihai PETRUȚ ${ }^{1}$
}

DOI: 10.21163/GT_2017.121.10

\begin{abstract}
:
Lately, computerized hydrologic models have become an essential tool not only for a better understanding of the hydrologic cycle but also for a faster problem solving in hydrology, such as the ungauged catchments. Since Covasna river, which is a left tributary of the Black river, is monitored only by two gauging stations, an approach for runoff modelling at the ungauged outlets within the catchment, would be extremely beneficial. Thus, the main purpose of this study is to conduct a test of the ability of such a simulation modeling system for flood prediction within the upstream catchment area of Covasna river. The one chosen for carrying out this study, HEC-HMS, is known to be a reliable model with reasonable approximations. Throughout the research, ArcHydro and HEC-GeoHMS extensions are used to delineate the watershed, and to obtain the hydraulic length, the $\mathrm{CN}$ grid and other parameters. This study is also a solution for the problem of long simulation time of the model, by following first, the work flow implemented in ArcGis 10.2 through Model Builder.
\end{abstract}

Key-words: Small basins, Hydrological model, SCS method, Snyder unit hydrograph, ModelBuilder, Ungauged basins, Maximum discharge

\section{INTRODUCTION}

The usage of hydrological models is very important nowadays in order to simulate the spatial and temporal variation of water fluxes. Lately, the problem of ungauged subwatersheds prone to flash floods was of great interest among the researchers.

The upstream area of Covasna watershed has always been affected by flash floods. Even if it is a gauged catchment, the flash flooding of its ungauged tributaries often causes problems to the local activities. The watershed is mostly covered with forests $(87,2 \%)$. Thereby, the forestry institutions conduct important activities within the area, not only for economic (exploitations), but also for environmental reasons (cleaning activities such as those related to the wind-damaged trees, broken tree trunks, torrent correction works and so on). The forest roads along the main river's ungauged tributaries, are often affected by flash floods due to the heavy rain or snow melting. Such events may greatly affect the forestry activities.

Măliguța et al. (2009) used the example of Covasna county as being one of the most affected by deforestation in Romania based on data from the Research Institute of Forest Landscaping. Buhalău (2016) used a decomposition method to detect the deforestation within the area between 2005 and 2015, and also data from the National Institute of Statistics in order to compare the results. According to the Institute's data sets, in the year

\footnotetext{
${ }^{1}$ Babeş-Bolyai University, Faculty of Geography, 400006, Cluj-Napoca, Cluj County, Romania carinastrapazan@yahoo.ro; petrut.mihai99@yahoo.ro
} 
of 2011, 2501 ha of trees were cut down. If not rationally done, these activities may alter the flow regime of the rivers. Applying the "Long-Term Flood Risk Management Strategy", involves torrent correction works among other activities.

The lack of hydrological predictions for small-scale ungauged basins affects the local authorities who carry out such activities. This problem concerns the headwater areas of Covasna as well. Therefore, the main purpose of this research consists of simulating the maximum discharge during the flash flood which started on June 10th, 2011 (one of the greatest in the last 5 years, with hourly rainfall data available) by using the ArcHydro techniques and the HEC-HMS modeling system. The analysis of the HEC-HMS software's accuracy could give an answer to the question of whether or not it could be used for subsequent flood predictions. This software was chosen not only for its greater accessibility than other modeling systems (such as MIKE SHE, SHE etc.) and for its required input parameters (which can be computed using the G.I.S. tools), but also because of its very known efficiency.

The Hydrologic Engineering Corps Hydrologic Modeling System (HEC-HMS) is a generalized modeling system, developed by US Hydrologic Engineering Center-SMA capable of simulating the rainfall-runoff processes in various watersheds with the deterministic mathematical models included (USACE, 2000, 2010). This software was used for hydrologic modeling studies in small watersheds by many authors: Gyori \& Haidu (2011), Gyori et al., (2013), Khaddor \& Alaoui (2014), Haidu \& Ivan (2016), etc. Various different calculation methods can be selected to simulate the infiltration losses: SCS curve number, Green and Ampt, etc., or to transform the excess precipitation into surface runoff such as Clark, Snyder, SCS etc. (USACE 2000, 2010). Several studies such as those carried out by Xiaoyong \&Min-Lang (2004), Baltas et al. (2007), Crăciun et al. (2009), Shadeed \& Almasri (2010), Latha et al. (2012), Costache (2014), Malekani et al. (2014), Mishra \& Kansal (2014) used the SCS-CN method, which is among the most popular ones for predicting the surface runoff in watersheds. This method was also chosen in this study.It implies the use of the curve number $(\mathrm{CN})$, which is the primary input parameter for the runoff equation.

Another study carried out by Gyori et al. (2016), used the SCS-CN method and the HEC-HMS software in order to compute the discharge values of different return periods for three small rivers located in the Zarandului Mountains (Romania). This values served as entry data for the Mike11 hydraulic model.

In order to perform the rainfall-runoff modeling in the upstream catchments of Covasna river, the first step was to generate the weighted $\mathrm{CN}$ and the other parameters required by HEC-HMS through Archydro (such as hydraulic length and average slope).

With the usage of GIS and its add-ons, Hec-GeoHMS and Archydro, the process of computing not only the $\mathrm{CN}$, but also another parameters for a given area or a watershed, becomes faster and more efficient. The models created in ArcGis through ModelBuilder can be used to streamline the process of runoff simulation. The second part of the research is based on the actual modeling, the analysis of the runoff evolution down to the Covasna gauging station and of the simulated flow compared to the measured one.

\section{STUDY AREA}

The upstream catchment area of Covasna river is located within the county of Covasna and has an area of $39 \mathrm{~km}^{2}$ (calculated in ArcGIS). Covasna, which is a left tributary of The Black river, is monitored by two gauging stations which belong to the Olt Basinal Water 
Administration and the gauged upstream watershed is located in the western side of the Curvature Carpathians.

The land use within the basin especially consists of coniferous trees $(71,5 \%)$ and mixed woods $(15,7 \%)$. The soil coverage consists of various types: Dystricambosols $(72,8 \%)$, Luvisols (11\%), Prepodzols (11\%) and Aluviosols (5\%). Regarding the watershed geology, the entire area lies on a complex of sandstone, marlstone rocks and siliceous schists.

The study area is situated upstream of Covasna city, which is the only human settlement within or close to the basin (Fig. 1).

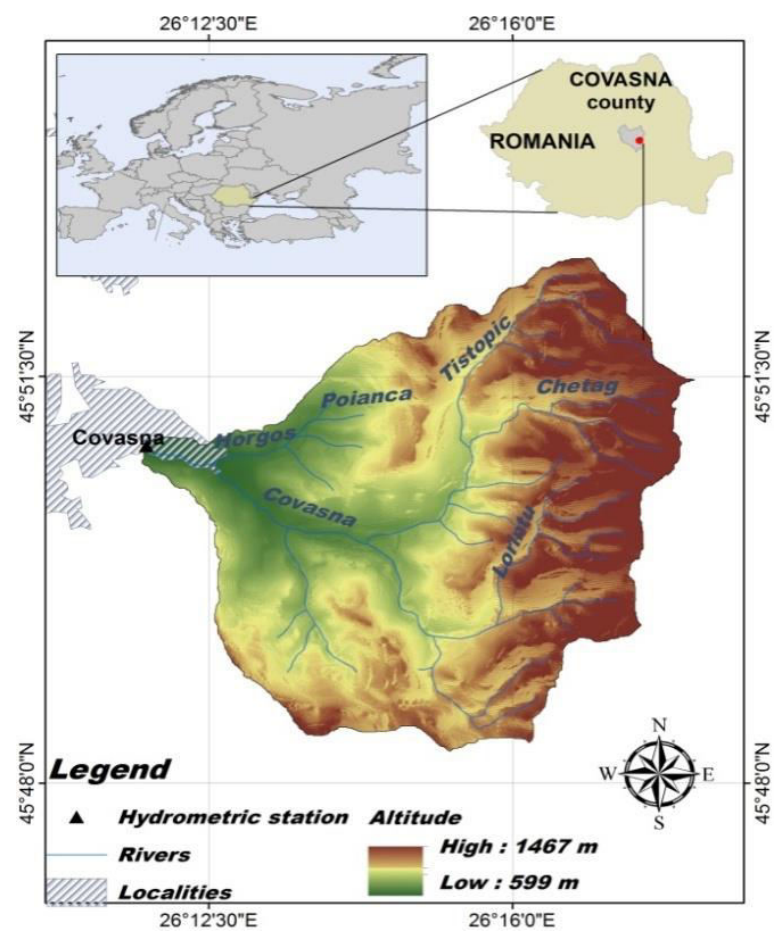

Fig. 1 The location of the area

\section{DATA AND METHODS}

A topographic map (scale 1:25000) was used in order to obtain the DEM (through interpolation of digitized contours), because of its higher resolution, than those available on the internet.

The ArcHydro model was developed to assist the hydrologic modeling, but in order to obtain the catchment delineation and the stream network, one needs to go through a considerable number of steps such as filling the artifact sinks from DEM creation, computing the flow direction, the flow accumulation and so on (Kraemer \& Panda, 2009). Thus, the process of drainage lines, points, catchments and adjoint catchments identification was automatically implemented in Model Builder (Fig. 2).

The main goal was to convert the output from ArcHydro model to an HEC-HMS project through Hec-GeoHMS tools (by creating a new project). However, before taking this step, the catchment was delineated by using the function of batch watershed 
delineation (after we created the batch point at the location of our interest). Then, the hydraulic length was computed through the function of Longest flow path for catchments and the slope grid (Fig. 3a) by using Terrain preprocessing-Slope (percent rise).

The average slope value for each subbasin was calculated through Zonal Statistics as Table. The next step was to create the $\mathrm{CN}$ grid, in order to extract the $\mathrm{CN}$ for the watershed and the subwatersheds. This parameter is based on the catchment's soil and land use characteristics, being used for the computation of runoff or infiltration from rainfall excess in the HEC-HMS modeling system (Khaddor \& Alaoui, 2014).

According to USDA (1986), the CN method is based on the following equation:

$$
Q=\frac{(P-0.2 S)^{2}}{(P+0.8 S)}
$$

Where: Q-runoff at time t (inches/mm); P-precipitation at time t (inches/mm); Spotential maximum retention (inches $/ \mathrm{mm}$ ).

According to many studies on small agricultural catchments, $I_{Q}$ (initial abstraction) was found to be computed through the following equation:

$$
I_{a}=0.2 S
$$

The potential maximum storage depends on the runoff curve number, according to the following formula:

$$
S=\frac{25400}{C N}-254
$$

The first step in computing the $\mathrm{CN}$, was to assign the soils within the area to hydrologic soil groups. This process depends on the classification system texture adjusted by Chendeș (2011) to our country.

There are four hydrologic soil groups characterized by various textures and infiltration capacities: A, B ,C and D. Group A soils have a high infiltration capacity and a reduced runoff potential, while group $\mathrm{D}$ soils have low infiltration rates and a high runoff potential (Chendeș 2011).

The soil analysis within the study area was possible due to the 1:200000 scale map provided by the National Research and Development Institute for Soil Science, Agrochemistry and Environment (ICPA Romania).

The $\mathrm{CN}$ depends also on the land use so that this layer was obtained from the Corine Land Cover (CLC2006) database (Fig. 3b) with landcover types for each European country grouped into 44 classes. In the attribute table, a new column storing the codes for each land use from the table published by Chendeș (2011) was added.

The soil and land use data were merged. Then, a CN Lookup table containing the values of each soil group and land use combination was created. Thus, 6 columns were added to the table, 4 corresponding to each hydrologic soil group: A, B, C, D and the CN values, one storing the same codes for each land cover, and another one describing the land type itself. The values of $\mathrm{CN}$ within the study area range from 60 to 90 close to the urban area of Covasna (Fig. 3c) 


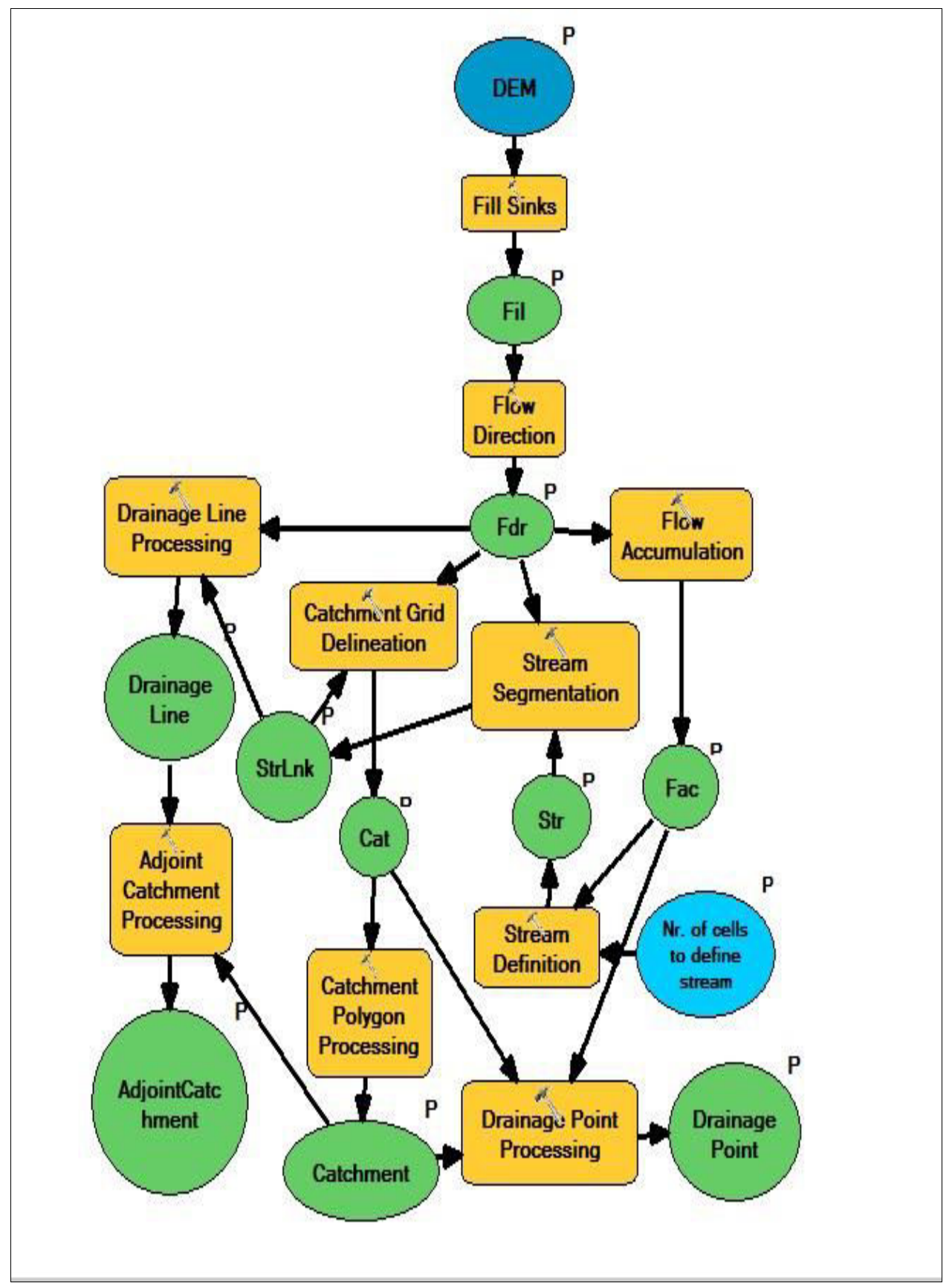

Fig. 2 The model for the ArcHydro process 


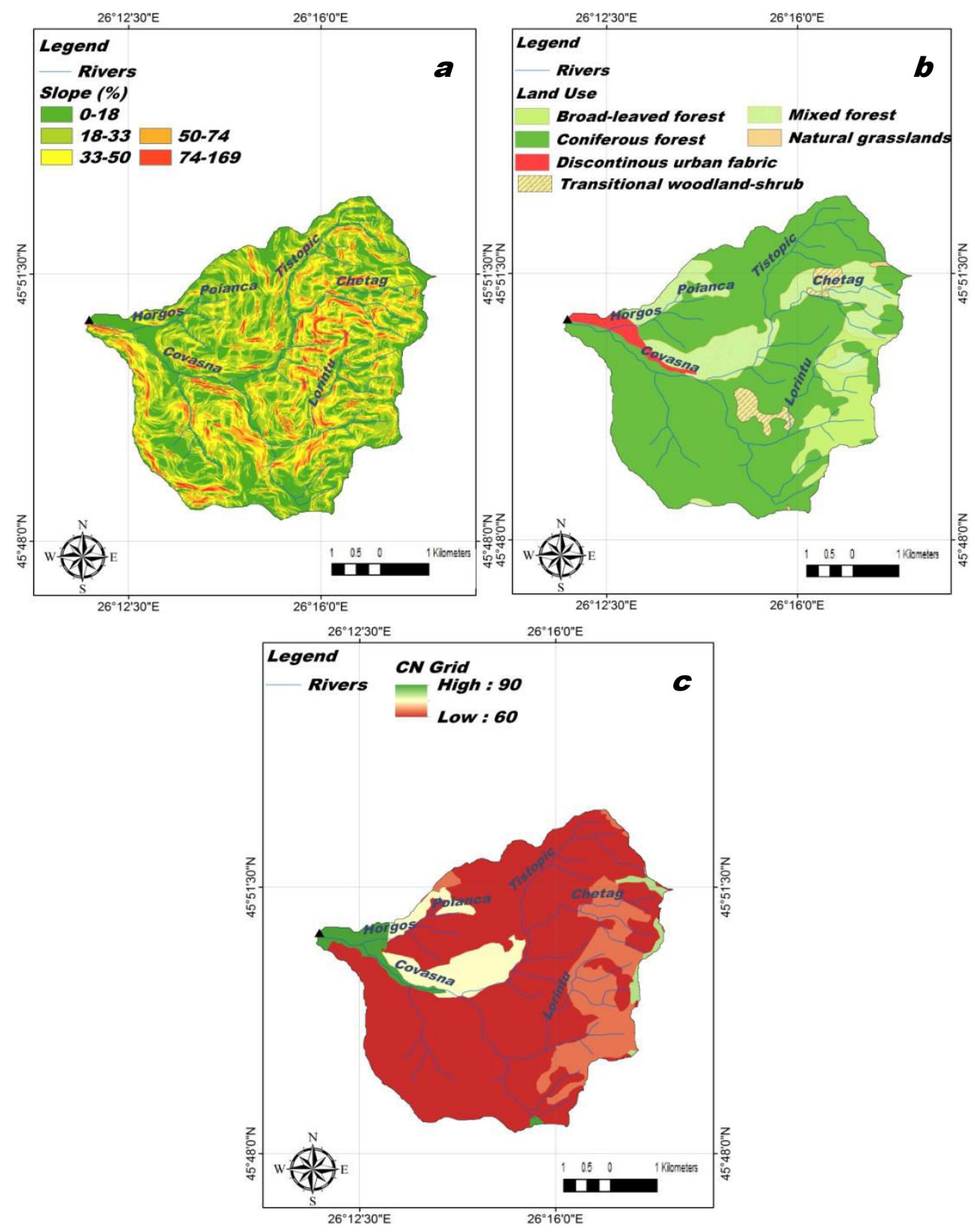

Fig. 3 The parameters obtained in ArcHydro and Hec-Geo HMS

Note: a-Slope map, b- Land use map, c-CN grid map of the study area

In order to reduce the time of extracting the $\mathrm{CN}$ for the study area, the process has been performed through Model Builder (Fig. 4), using the Hec-Geo-HMS tools (Generate CN Grid). 


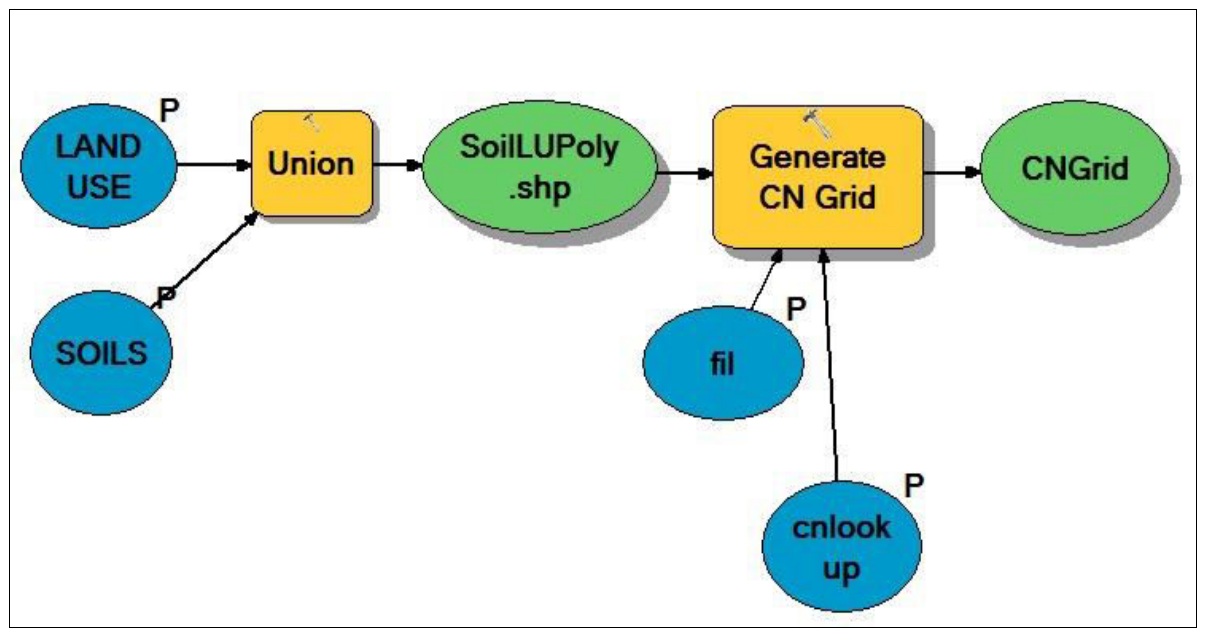

Fig. 4 The model for obtaining the $\mathrm{CN}$ grid

The next step was to calculate the area-weighted $\mathrm{CN}$ for each subbasin, according to the following equation (USACE,2000):

$$
C N_{w}=\frac{\sum_{i=1}^{n} C N_{i} A_{i}}{\sum A_{i}}
$$

Where: $C N_{W}$-area-weighted curve number; $C N_{i}$-the curve number for each land use-soil combination; $\mathrm{A}_{\mathrm{i}}$-the area for each land use-soil combination; $\mathrm{n}$-the number of land use-soil combinations.

The obtained values were adjusted according to the antecedent moisture condition (AMC) based on the amount of precipitation accumulated within the previous 5 days prior to the flash flood event.

Therefore, the parameters obtained in ArcHydro, were used to compute the time lag, using the SCS formula adapted by DHI (2007):

$$
T_{\text {lag }}=\frac{\left(\llbracket L * 3.28 * 10^{3}\right) \rrbracket^{0.8 *\left(\frac{1000}{C N}-9\right)^{0.7}}}{1900 Y^{0.5}}
$$

Where: $\mathrm{T}_{\text {lag }}$-lag time (hr); L-hydraulic length of the cachment/subcatchment $(\mathrm{km})$; CNthe area-weighted curve number; Y-average catchment slope (percent).

The time of concentration $\left(\mathrm{T}_{\mathrm{c}}\right)$ was automatically computed through HEC-HMS based on the lag time.

On the basis of the lag time, the concentration time may be also computed, using the following equation (USDA, 2010): 


$$
T_{C}=1.67 * T_{\operatorname{lag}}
$$

Where: Tlag-lag time (hr); Tc-time of concentration (hr).

An example of some computed parameters for a few larger subbasins (within which forestry activities are likely to occur more often), and also for the entire watershed is shown in Table 1.

Table 1.

Morphometric parameters computed through ArcHydro Tools

\begin{tabular}{|c|c|c|c|c|c|}
\hline Subbasin & $\begin{array}{c}\text { Area } \\
\left(\mathrm{km}^{2}\right)\end{array}$ & $\begin{array}{c}\text { Flow } \\
\text { length } \\
(\mathrm{km})\end{array}$ & $\begin{array}{c}\text { Basin } \\
\text { mean } \\
\text { alt. }(\mathrm{m})\end{array}$ & $\begin{array}{c}\text { "0,, } \\
\text { reference } \\
\text { level }(\mathrm{m})\end{array}$ & $\begin{array}{c}\text { Time of } \\
\text { concentration } \\
(\mathrm{hr})\end{array}$ \\
\hline Tistopic & 5.1 & 5.4 & 1098 & M.A.S.L & 3.0 \\
\hline Chetag & 9.1 & 7.0 & 1124 & M.A.S.L & 3.2 \\
\hline Subbasin 2 & 2.9 & 3.8 & 1099 & M.A.S.L & 2.5 \\
\hline Subbasin 3 & 4.5 & 4.5 & 984 & M.A.S.L & 2.5 \\
\hline Covasna & 39.0 & 12.2 & 774 & M.A.S.L & 3.7 \\
\hline
\end{tabular}

Note: M.A.S.L-meters above sea level (The Black Sea)

For the upper Covasna river catchment, HEC-HMS was used to analyze the evolution of the discharge from upstream to downstream catchment areas (down to the gauging post, the outlet of the watershed) at every confluence, by applying the rainfall event which lasted from 10 June 2011 until 12 June 2011, measured at the Covasna hydrometric station.

All of the subbasins were introduced in the basin model along with their physical parameters previously calculated through the HEC-GeoHMS tool . Thus, the catchment was divided into 14 interconnected subbasins.

The time series of precipitation data were the input for the meteorological model defined. Thereby, the rainfall event was assigned to all of the subbasins in the model (by the specified hyetograph method), assuming that it is distributed evenly over the entire catchment (given its small area).

\section{RESULTS}

The simulated hydrograph at the sink point (which corresponds with the Covasna gauging station), was compared to the observed one, by using the SCS CN loss method. Two different transform methods were used instead, with the aim of analyzing the accuracy of the model and to make a comparison between them: the SCS Unit hydrograph (SCS-UH) and the Snyder Unit hydrograph (Snyder-UH).

The parameters required for the SCS CN Loss method are the curve number, the initial abstractions and the percent impervious (if not included into the curve number).

The percent impervious (e.g. rooftops, roads, parking lots) is one of the elements that can substantially influence the runoff. Ivan (2015) analyzed the impervious surfaces within the city of Cluj-Napoca using Landsat satellite imagery and the method of Maximum Likelihood. Parece \& Campbell (2013), used Landsat images as well, but also aerial photography. The impervious surfaces of the Big Darby Creek watershed, were represented by the values of the $\mathrm{CN}$ in the study conducted by Ahn et al. (2014) who developed the 
regression model to adjust them. The impervious areas in this study, were included while computing the CN (based on the CLC data). HEC-HMS automatically calculates the initial abstraction considering the $\mathrm{CN}$.

As opposed to the SCS Unit Hydrograph transform method, another parameter is required (other than the lag time), for the Snyder Unit Hydrograph, namely the peaking coefficient (Cp). This parameter can be determined through model calibration because it is not directly related to any physical characteristic (USACE,2000). In this study, calibration was used to estimate the peaking coefficient.

The inflows were simulated through both methods at each junction. Simulated peak flows occured faster, about 2-3 hours earlier, for the SCS-UH transform method compared to the Snyder one (Table 2.).

The use of the historical discharge records allowed the model validation. According to the recorded data, the river reached its highest level, $16 \mathrm{~m}^{3} / \mathrm{s},(410.3 \mathrm{l} / \mathrm{s} / \mathrm{sq} . \mathrm{km})$ at $12 \mathrm{a} . \mathrm{m}$, June 11, 2011.

It was observed that the runoff hydrograph peak flow obtained for the SCS transform method at the sink point was higher by $23,4 \%$ than the one recorded and by $24,4 \%$ than the one obtained through the Snyder method.. It was also a great difference in the timing of the peak discharges (about 3 hours).

The peak flow obtained for the Snyder method was lower by only $1,3 \%$ than the one observed with a minor difference in the timing of the peak (about 10 minutes).

Table 2.

An example of simulated peak discharges for both transform methods

\begin{tabular}{|c|c|c|c|c|c|c|}
\hline \multirow{2}{*}{$\begin{array}{c}\text { Hydrologic element } \\
\text { (River/Subbasin/Junction) }\end{array}$} & \multicolumn{2}{|c|}{ SCS } & \multirow{2}{*}{ Time of Peak } & \multicolumn{2}{|c|}{ Snyder } & \multirow{2}{*}{ Time of Peak } \\
\hline & $\begin{array}{c}Q \\
\left(\mathrm{~m}^{3} / \mathrm{s}\right)\end{array}$ & $\begin{array}{c}q \\
\left(\mathrm{l} / \mathrm{s} / \mathrm{km}^{2}\right)\end{array}$ & & $\begin{array}{c}Q \\
\left(\mathrm{~m}^{3} / \mathrm{s}\right)\end{array}$ & $\begin{array}{c}q \\
\left(1 / s / \mathrm{km}^{2}\right)\end{array}$ & \\
\hline Junction-1 & 6.7 & 692.9 & 10Jun2011, 21:51 & 5.0 & 517.1 & 11Jun2011, 00:33 \\
\hline Chetag & 4.4 & 483.5 & 10Jun2011, 21:55 & 3.3 & 362.6 & 11Jun2011, 00:34 \\
\hline Tistopic & 2.3 & 454.5 & 10Jun2011, 21:44 & 1.7 & 336.0 & 11Jun2011, 00:32 \\
\hline Junction-3 & 4.8 & 556.8 & 10Jun2011, 20:48 & 3.4 & 394.4 & 11Jun2011, 00:09 \\
\hline Junction-2 & 2.7 & 600.0 & 10Jun2011, 20:47 & 1.9 & 422.2 & 11Jun2011, 00:08 \\
\hline Subbasin-2 & 1.5 & 517.2 & 10Jun2011, 21:10 & 1.1 & 379.3 & 11Jun2011, 00:19 \\
\hline Junction-5 & 15.4 & 485.5 & 10Jun2011, 21:08 & 11.8 & 372.0 & 11Jun2011, 00:16 \\
\hline Junction-4 & 12.2 & 472.5 & 10Jun2011, 21:15 & 9.5 & 367.9 & 11Jun2011, 00:18 \\
\hline Subbasin-3 & 2.2 & 488.9 & 10Jun2011, 21:11 & 1.6 & 355.6 & 11Jun2011, 00:20 \\
\hline COVASNA Post (Sink-1) & 20.9 & 535.9 & 10Jun2011, 20:57 & 15.8 & 405.1 & 11Jun2011, 00:11 \\
\hline Junction-7 & 20.1 & 523.4 & 10Jun2011, 21:01 & 15.2 & 395.8 & 11Jun2011, 00:13 \\
\hline
\end{tabular}

The basin model along with a few simulated hydrographs at some confluences are shown in Fig.5 and Fig. 6.

The rising limb of the simulated hydrograph resembles the observed one, but there are large differences between the recession ones. Thus, the program underestimates the flood volume, which can be caused by the lack of input data (regarding the baseflow or the rainfall for instance). 

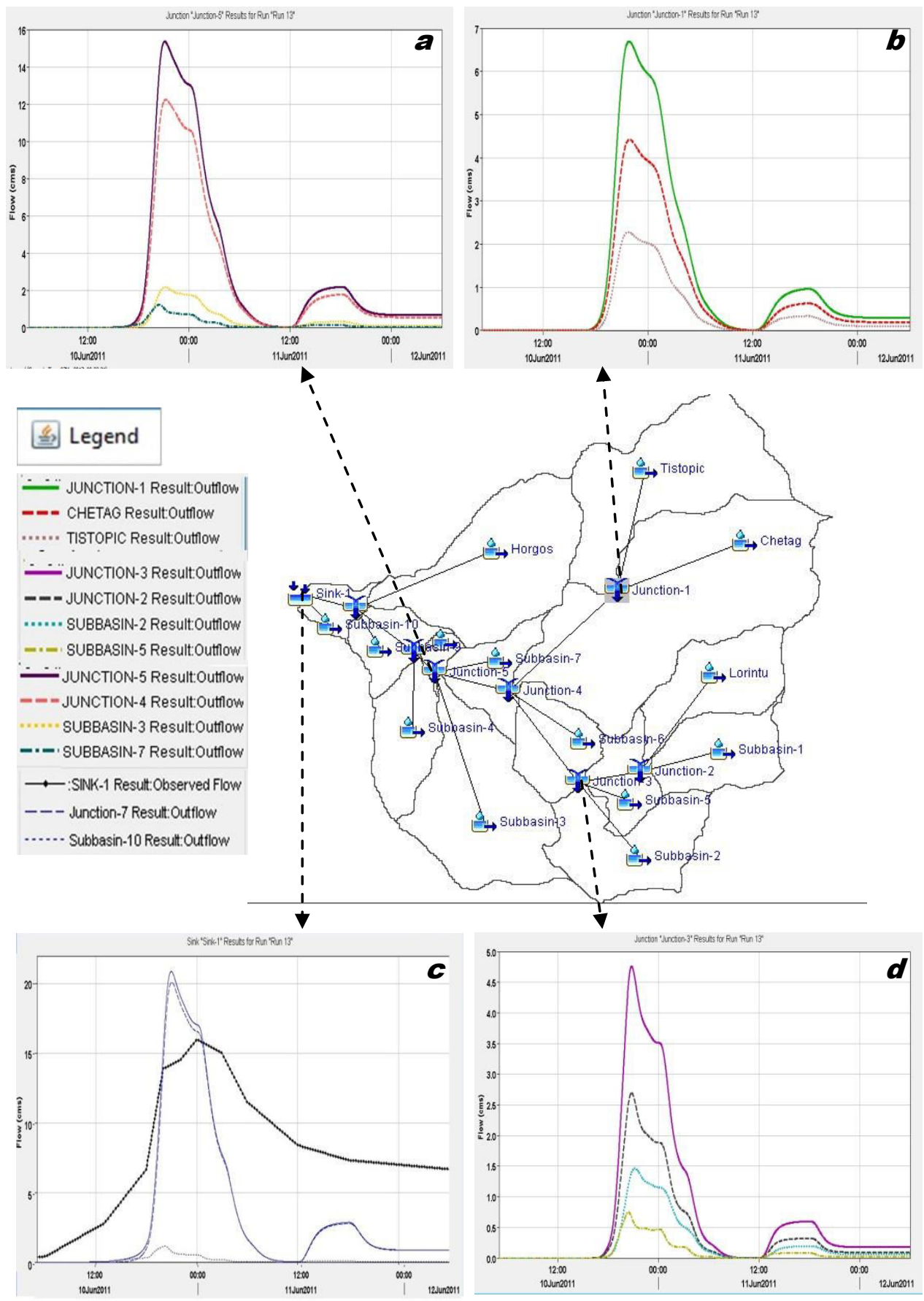

Fig. 5 The semi-distributed structure of the HEC-HMS model for the SCS method-the runoff hydrographs

Note:a-at Junction 5; b-at Junction 1; c-at the gauging station ; d-at Junction 3 

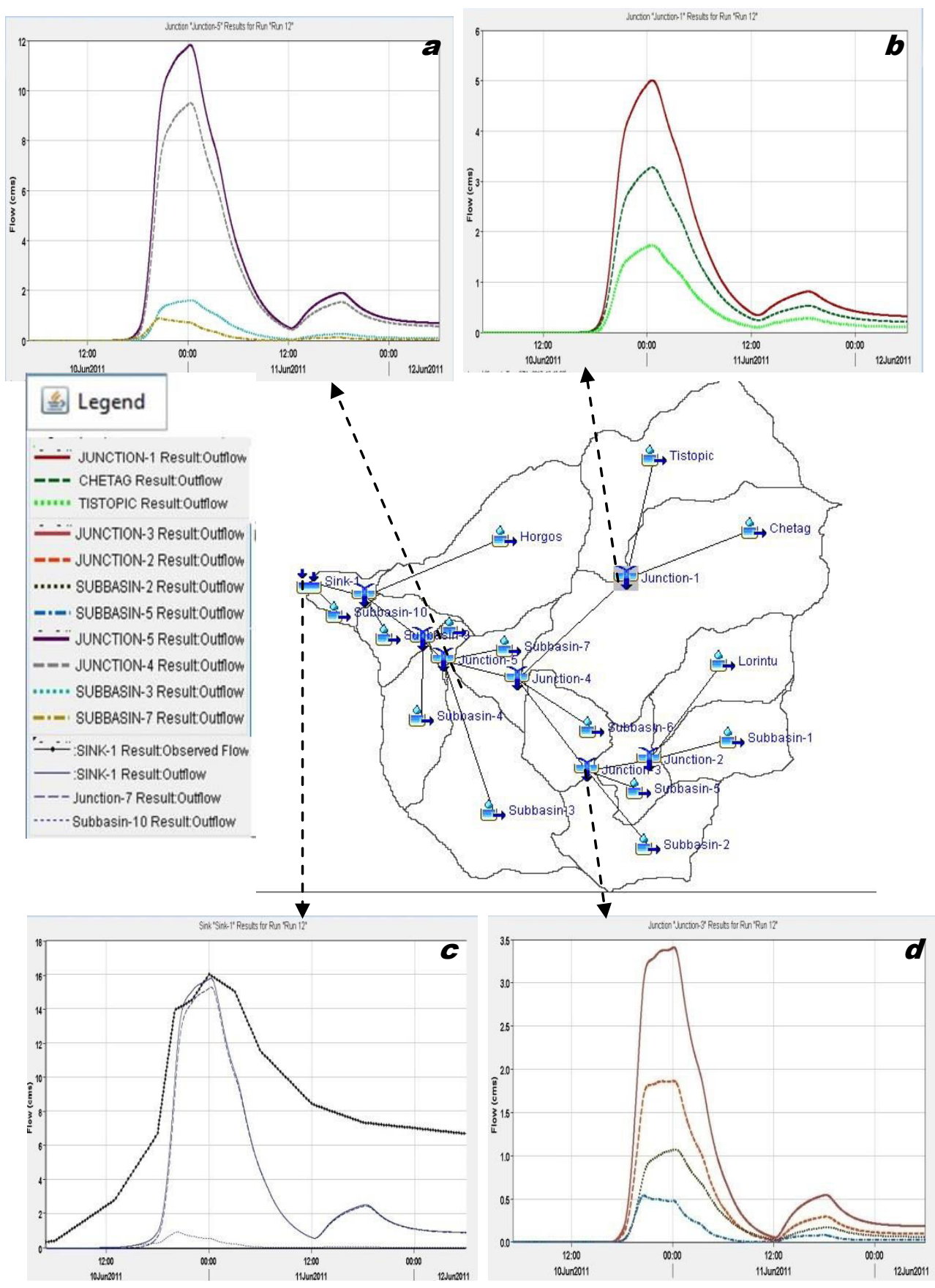

Fig. 6 The semi-distributed structure of the HEC-HMS model for the Snyder method-the runoff hydrographs

Note:a-at Junction 5; b-at Junction 1; c-at the gauging station ; d-at Junction 3. 


\section{CONCLUSIONS}

A good torrential basin management practice, requires a detailed knowledge of its related maximum rate of flow. This study presented not only a rainfall-runoff simulation for Covasna's tributaries and certain junctions, capable of helping the local authorities who often perform forestry activities within the area, but also a reliable and faster method for obtaining the required input parameters in HEC-HMS through Archydro and HecGeoHMS. Thus, the two extensions application techniques, facilitated the hydrological modeling by saving time. By using these techniques, the runoff processes were simulated for each subbasin and junction through HEC-HMS modeling system.

Despite the discrepancy between the observed and the simulated hydrographs through SCS method, results showed that the HEC-HMS model performed broadly well in estimating the peak discharge through Snyder technique Although the SCS transform method is recommended by many studies, the Snyder method had the highest efficiency in flow simulation (both in terms of peak values and time).

Nevertheless, both cases showed rapid increases and subsequent decreases of the simulated flow compared to the measured one. This led to high discordances between the water volumes. Anyway these differences may be caused by the lack of rain gauges within the watershed, baseflow data and so on.

\section{AKNOWLEDGEMENT}

This study was assisted by grants from the Romanian Ministry of Education and Scientific Research, as part of a larger doctoral research.

\section{R E F E R E N C ES}

Ahn, G. C., Gordon, S. I. \& Merry, C. J. (2014) Impacts of Remotely Sensed Land Use Data on Watershed Hydrologic Change Assessment. International Journal of Geospatial and Environmental Research, [Online] 1(1). Available from: http://dc.uwm.edu/ijger/vol1/iss1/9/ [Accessed 12Oct 2016].

Baltas, E. A., Dervos, N. A. \& Mimikou, M. A. (2007) Technical Note: Determination of the SCS initial abstraction ratio in an experimental watershed in Greece, Hydrology and Earth System Sciences, 11,1825-1829.

Buhalău, T. (2016), Detecting clear-cut deforestation using Landsat data: A time series analysis of remote sensing data in Covasna County, Romania between 2005 and 2015. Master degree thesis, Lund University, Lund.

Chendeș, V. (2011), Resursele de apa din Subcarpatii de la Curbura. Evaluari geospatiale, Bucharest, Romanian Academy Publishing.

Costache, R. (2014) Using GIS techniques for assessing lag time and concentration time in small river basins. Case study: Pecineaga river basin, Romania. Geographia Technica, 9 (1),31-38.

Crăciun, A. I, Haidu, I., Magyari-Sáska, Zs. \& Imbroane, A. I. (2009) Estimation of runoff coefficient according to soil moisture using GIS techniques. Geographia Technica, 4 (2), 1-10.

DHI Water \& Environment, (2007) A Modelling system for rivers and channels - Mike 11 Reference Manual. Horsholm, Denmark, Danish Hydraulic Institute.

Gyori, M. M. \& Haidu I. (2011) Unit Hydrograph Generation for Ungauged Subwatersheds. Case Study: the Monoroştia River, Arad County, Romania. Geographia Technica, 6 (2), 23 - 29. 
Gyori, M. M., Haidu, I. \& Humbert J. (2016) Deriving the floodplain in rural areas for high exceedance probability having limited data source. Environmental Engineering and Management Journal, 15 (8), 1879-1887.

Gyori, M. M., Humbert, J. \& Haidu, I.,(2013) Deriving flash floods in the case of simulated precipitations. Geographia Napocensis, 7 (2), 11-18.

Haidu, I. \& Ivan, K. (2016) Évolution du ruissellement et du volume d'eau ruisselé en surface urbaine. Étude de cas : Bordeaux 1984- 2014, France. La Houille Blanche, 5, 1-6.

Ivan, K. (2015) The spatio-temporal analysis of impervious surfaces in Cluj-Napoca, Romania. Geographia Technica, 10 (2), 50-58.

Khaddor, I. \& Alaoui, A. H. (2014) Production of a Curve Number map for Hydrological simulation - Case study: Kalaya Watershed located in Northern Morocco. International Journal of Innovation and Applied Studies, 9 (4), 1691-1699.

Kraemer, C. \& Panda, S. S. (2009) Automating ArcHydro for watershed delineation,In: The University of Georgia, Water Resources Faculty (ed.). Proceedings of the 2009 Georgia Water Resources Conference. Athens, Georgia U.S.A, Warnell School of Forestry and Natural Resources, The University of Georgia, pp.428-433.

Latha, M., Rajendran, M. \& Murugappan, A. (2012) Comparison of GIS based SCS-CN and Strange table Method of Rainfall-Runoff Models for Veeranam Tank, Tamil Nadu, India. International Journal of Scientific \& Engineering Research, 3 (10), 1-5.

Malekani, L., Khaleghi, S. \& Mahmoodi, M. (2014) Application of GIS in modeling Zilberchai Basin runoff. The International Archives of the Photogrammetry, Remote Sensing and Spatial Information Sciences, 42 (3), 181-186.

Măliguța, S. A., Cîrja, L., Băghină, N. (2009), The Consequences of Deforestation on the Environment, Research Journal of Agricultural Science, 41 (3), 92-95.

Mishra, S. K. \& Kansal A. K. (2014) A procedure for determination of design runoff curve number for a watershed. Journal of Indian Water Resources Society,34(3), 46-56.

Parece, T. E. \& Campbell, J. B. (2013) Comparing Urban Impervious Surface Identification Using Landsat and High Resolution Aerial Photography. Remote Sensing, 5(10), 4942-4960.

Shadeed, S. \& Almasri, M. (2010) Application of GIS-based SCS-CN method in West Bank catchments, Palestine. Water Science and Engineering, 3 (1), 1-13.

US Army Corps of Engineers-Institute For Water Resources (2000), CPD-74B. Hydrologic Modeling System HEC-HMS, Technical Reference Manual. Davis, CA U.S.A, Hydrologic Engineering Center.

US Army Corps of Engineers-Institute For Water Resources (2010), CPD-74A. Hydrologic Modeling System HEC-HMS, User's Manual. Davis, CA U.S.A, Hydrologic Engineering Center.

USDA Natural Resources Conservation Service (2010), National Engineering Handbook. Time of concentration, 210-VI-NEH, Part 630 Washington D. C, U.S. Dept. of Agriculture.

USDA Natural Resources Conservation Service, (1986). Urban Hydrology for Small Watersheds. 210-VI-TR-55, Second Ed., Washington, D. C.: U. S. Dept. of Agriculture.

Xiaoyong, Z. \& Min-Lang, H. (2004) ArcCN-Runoff: an ArcG.I.S. tool for generating curve number and runoff maps. Environmental Modelling \& Software, 19 (10), 875-879. 